\title{
Pengaruh Pupuk Organik Guano dan Chitosan terhadap Pertumbuhan dan Perkembangan Anggrek Phalaenopsis spp.
}

\section{The Effect of Organic Fertilizer Guano and Chitosan on the Growth and Development of Phalaenopsis spp. Orchids}

\author{
Ira Fauziah Noer, Dewi Sukma* dan Sandra A. Aziz
}

Departemen Agronomi dan Hortikultura, Fakultas Pertanian, Institut Pertanian Bogor (Bogor Agricultural University), Jl. Meranti, Kampus IPB Darmaga, Bogor 16680, Indonesia Telp.\&Faks.62-251-8629353 e-mail agronipb@indo.net.id

*Penulis untuk korespondensi: dsukma70@yahoo.com

Disetujui : 14 November 2015 / Published online 12 Desember 2015

\begin{abstract}
This research was conducted to determine the effect of organic fertilizer guano and chitosan on the growth and development of phalaenopsis orchid conducted in the Gunung Batu nursery, Bogor in March until August 2011. This research used a completely randomized block design with 4 treatments and 4 replications. Fertilizer treatments consisted of Thaichung fertilizer $1 \mathrm{~g} \mathrm{~L}^{-1}$, Thaichung fertilizer $1 \mathrm{~g} \mathrm{~L}^{-1}+$ chitosan $10 \mathrm{ppm}$, Thaichung fertilizer $1 \mathrm{~g} \mathrm{~L}^{-1}+$ guano $10 \mathrm{ml} \mathrm{L}^{-1}$, and Thaichung fertilizer $1 \mathrm{~g} \mathrm{~L}^{-1}+$ chitosan $10 \mathrm{ppm}+$ guano $10 \mathrm{ml} \mathrm{L} \mathrm{L}^{-1}$. Thaichung fertilizer $1 \mathrm{~g} \mathrm{~L}^{-1}$ were needed for P. bellina and P. modesta, and guano $10 \mathrm{ml} L^{-1}$ were needed for $P$. amabilis in compote in the hot and dry conditions.
\end{abstract}

Keywords : completely randomized block design, compot, P.amabilis

\section{ABSTRAK}

Penelitian dilakukan untuk mengetahui pengaruh pupuk organik guano dan kitosan pada pertumbuhan dan perkembangan anggrek Phalaenopsis dilakukan di pembibitan Gunung Batu, Bogor pada bulan Maret sampai Agustus 2011. Penelitian menggunakan rancangan kelompok lengkap teracak dengan 4 perlakuan dan 4 ulangan. Perlakuan pemupukan terdiri atas pupuk Thaichung $1 \mathrm{~g} \mathrm{~L}^{-1}$, pupuk Thaichung $1 \mathrm{~g} \mathrm{~L}^{-1}+$ kitosan 10 ppm, Thaichung pupuk $1 \mathrm{~g} \mathrm{~L}^{-1}+$ guano 10 $m l L^{-1}$, dan pupuk Thaichung $1 \mathrm{~g} \mathrm{~L}^{-1}+$ kitosan $10 \mathrm{ppm}+$ guano $10 \mathrm{ml} \mathrm{L}^{-1}$. pupuk Thaichung $1 \mathrm{~g} \mathrm{~L}^{-1}$ yang dibutuhkan untuk $P$. bellina dan P. modesta, dan guano $10 \mathrm{ml} \mathrm{L}^{-1}$ yang dibutuhkan untuk $P$. amabilis di kompot dalam kondisi panas dan kering.

Kata kunci: kompot, P.amabilis, rancangan kelompok lengkap teracak 


\section{PENDAHULUAN}

Anggrek merupakan salah satu tanaman suku Spermatophyta yang unik dan termasuk dalam famili Orchidaceae. Salah satu anggrek yang digemari adalah Phalaenopsis. Anggrek ini memiliki keragaman bunga yang tidak diragukan lagi keindahannya. Bentuk, ukuran, dan warnawarni bunganya memberikan nilai lebih pada anggrek Phalaenopsis dibandingkan dengan anggrek lainnya. Indonesia merupakan negara tropis yang memiliki berbagai jenis spesies anggrek Phalaenopsis, diantaranya Phalaenopsis amabilis, Phalaenopsis bellina, Phalaenopsis modesta, dan lain sebagainya. Spesies-spesies asli tersebut harus dilindungi dan dipelihara sehingga dapat dimanfaatkan dalam pengembangan varietas baru anggrek.

Pertumbuhan dan perkembangan anggrek dipengaruhi oleh kondisi lingkungan. Kondisi lingkungan dapat dibagi menjadi beberapa komponen yaitu iklim yang meliputi cahaya, suhu, dan kelembaban serta faktor lain diantaranya jenis media dan pemupukan. Virnanto (2010) menyatakan bahwa anggrek Phalaenopsis merupakan tipe tanaman yang memiliki kecepatan tumbuh yang relatif lambat, sedangkan jenis anggrek silangan seperti Dendrobium maka pertumbuhan dan pembungaan relatif lebih cepat. Sandra (2005) menyatakan bahwa kebutuhan sinar matahari Phalaenopsis lebih rendah daripada Dendrobium yaitu sekitar $10-30 \%$ untuk Phalaenopsis dan 40-50\% untuk Dendrobium, tetapi kedua jenis anggrek ini sama-sama membutuhkan naungan.

Pupuk organik guano adalah pupuk yang berasal dari kotoran dari jenis burung laut (contohnya Larus argentatus) dan kelelawar (contohnya Phylloncyteris aphylla). Manfaat dari pupuk guano yaitu memperbaiki dan memperkarya struktur tanah karena $40 \%$ pupuk ini mengandung material organik, terkandung bakteria dan mikrobiotik flora yang bermanfaat bagi pertumbuhan tanaman dan sebagai fungisida alami, dan mengontrol nematode merugikan yang ada di dalam tanah (Seta, 2009). Selain aplikasi pemupukan, pertumbuhan dan perkembangan anggrek dapat dibantu dengan pemberian bahan organik seperti chitosan.

Chitosan adalah poli-(2-amino-2-deoksi$\beta$-(1-4)-D-glukopiranosa) dengan rumus molekul $\left(\mathrm{C}_{6} \mathrm{H}_{11} \mathrm{NO}_{4}\right)_{\mathrm{n}}$ yang dapat diperoleh dari deasetilasi kitin. Chitosan merupakan zat anti bakteri, efektif dalam menghambat pertumbuhan bakteri, hal ini disebabkan karena memiliki polikation alami yang mampu menghambat pertumbuhan bakteri dan kapang (Susanto et al., 2008). Chitosan dengan konsentrasi $10 \quad \mathrm{mg} \mathrm{L} \mathrm{L}^{-1}$ dapat meningkatkan pertumbuhan tanaman anggrek dendrobium muda (Chandrkrachang, 2002). Penelitian ini bertujuan untuk mengetahui pengaruh pupuk organik guano dan chitosant terhadap pertumbuhan dan perkembangan beberapa spesies anggrek Phalaenopsis.

\section{BAHAN DAN METODE}

Penelitian dilaksanakan di nursery Gunung Batu, Bogor dari bulan Maret sampai Agustus 2011. Lokasi berada pada ketinggian sekitar $250 \mathrm{~m}$ dpl. Pembuatan larutan chitosan di Laboratotium Pasca Panen dan untuk bibit anggrek $P$. Amabilis di Institut Pertanian Bogor.

Bahan-bahan yang digunakan adalah beberapa spesies anggrek Phalaenopsis, yang terdiri atas Phalaenopsis bellina, Phalaenopsis modesta, dan bibit Phalaenopsis amabilis. P. bellina dan $P$. modesta dengan umur tanaman yang sudah dewasa \pm 2 tahun ditanam pada blok pakis, sedangkan bibit $P$. amabilis berasal dari kultur jaringan ditanam pada pot tanah liat dengan media tanam sphagnum moss. Pemupukan menggunakan pupuk organik guano $(0.93 \% \mathrm{~N}$, $2.13 \% \mathrm{P}, 2.80 \% \mathrm{Ca}, 1.73 \% \mathrm{Mg}, 1.11 \% \mathrm{~K}$ ), chitosan, dan pupuk daun Taichung (12\% N, $12 \%$ $\mathrm{P}, 10.5 \% \mathrm{~K}$, dan $16 \% \mathrm{Ca}$ ), asam asetat $1 \%$, fungisida (benlox) dan bakterisida (plantomycin). Alat yang digunakan adalah timbangan, sprayer, meteran, greenmeter atau SPAD, dan alat-alat penunjang lainnya.

Penelitian terdiri atas tiga percobaan terpisah untuk 3 spesies ( $P$. bellina, $P$. modesta, dan bibit $P$. amabilis). Setiap percobaan menggunakan metode Rancangan Kelompok Lengkap Teracak (RKLT) dengan satu faktor yaitu perlakuan pupuk organik guano dan chitosan. Susunan perlakuan adalah sebagai berikut :

P1: Pupuk Taichung sesuai dosis rekomendasi $1 \mathrm{~g}$ $\mathrm{L}^{-1}$

P2: Pupuk Taichung $1 \mathrm{~g} \mathrm{~L}^{-1}+$ chitosan $10 \mathrm{ppm}$

P3: Pupuk Taichung $1 \mathrm{~g} \mathrm{~L}^{-1}+$ pupuk Guano $10 \mathrm{ml}$ $\mathrm{L}^{-1}$

P4: Pupuk Taichung $1 \mathrm{~g} \mathrm{~L}^{-1}+$ chitosan $10 \mathrm{ppm}+$ pupuk guano $10 \mathrm{ml} \mathrm{L}^{-1}$

Setiap perlakuan terdiri atas 4 ulangan dengan satu ulangan terdiri atas satu tanaman dengan umur \pm 2 tahun atau relatif sama untuk anggrek $P$. bellina dan $P$. modesta karena bahan tanam terbatas, sedangkan untuk bibit anggrek $P$. amabilis berasal dari kultur jaringan setiap perlakuan terdiri atas 3 ulangan. Analisis data dilakukan menggunakan analisis ragam uji F, jika berpengaruh nyata terhadap peubah yang diamati 
akan dilakukan uji lanjut dengan uji Beda Nyata Jujur (BNJ) untuk anggrek $P$. bellina dan $P$. modesta dan uji DMRT untuk bibit anggrek $P$. amabilis taraf 5\%. Analisis data untuk beberapa parameter pengamatan menggunakan analisis uji $t$ untuk peubah-peubah generatif tertentu karena tidak semua tanaman berbunga.

Pembuatan larutan chitosan untuk $P$. bellina dan $P$. modesta dilakukan dengan mencampurkan chitosan dengan asam asetat $1 \%$ hingga mengental, kemudian aquades dimasukkan ke dalam larutan chitosan. Perlakuan pupuk dilakukan setiap 4 hari sekali dengan konsentrasi sesuai perlakuan dan volume semprot sekitar 10$20 \mathrm{ml}$ per tanaman (tergantung ukuran tanaman). Pengamatan dilakukan selama 17 minggu setelah perlakuan. Peubah yang diamati meliputi : tinggi tanaman, panjang dan lebar daun terpanjang, jumlah daun, waktu keluar kuntum bunga, jumlah kuntum bunga, jumlah bakal bunga per tangkai, panjang tangkai bunga, daya tahan bunga di pohon, ukuran bunga, masa pembungaan, gejala serangan hama dan penyakit, dan tingkat kehijauan daun diukur dengan alat greenmeter atau SPAD.

Bibit anggrek $P$. amabilis dicelupkan pada larutan fungisida dan bakterisida sesuai dosis yang diperlukan yaitu masing-masing $1 \mathrm{~g} \mathrm{~L}^{-1}$. Setelah itu, bibit anggrek dikeringanginkan dan ditanam pada media tanam sphagnum moss, masing-masing pot berisi 5-7 bibit anggrek. Perlakuan pupuk hampir sama dengan $P$. bellina dan $P$. modesta yaitu dilakukan setiap 4 hari sekali dengan konsentrasi sesuai perlakuan dan volume semprot sekitar $10-30 \mathrm{ml}$ per pot. Pengamatan dilakukan selama 8 minggu setelah perlakuan. Peubah yang diamati, sebagai berikut : tinggi tanaman, panjang dan lebar daun terpanjang, dan jumlah daun.

\section{HASIL DAN PEMBAHASAN}

\section{Kondisi Umum}

Kondisi tanaman anggrek Phalaenopsis bellina dan Phalaenopsis modesta sebelum perlakuan cukup baik. Selama perlakuan kondisi tanaman secara umum baik, namun pada akhir bulan ketiga sampai awal bulan keempat yaitu pada akhir bulan Juni hingga awal Juli kira-kira pada 11 sampai 14 MSP tanaman mengalami kekeringan karena kondisi cuaca dan curah hujan yang tidak sesuai dengan ketahanan tanaman anggrek, sehingga daun banyak yang kuning, layu, serta ada beberapa tanaman yang mengalami kerontokan pada daun.
Bulan Juni dan Juli 2011 rata-rata lama penyinaran matahari 7.04 dan 6.96 jam, sedangkan intensitas penyinaran matahari 253 dan $272 \mathrm{cal} / \mathrm{cm}^{2} /$ menit. Data tersebut lebih tinggi dengan syarat tumbuh tanaman anggrek yaitu lama penyinaran matahari 10-30\% (Dewi, 2006). Pengendalian masalah tersebut dilakukan dengan penambahan penggunaan paranet dan pemberian vitamin $\mathrm{B} 1$ dengan konsentrasi $25 \mathrm{mg} \mathrm{L}^{-1}$. Pengendalian tersebut memberikan efek positif bagi tanaman anggrek. Tanaman kemudian terlihat lebih segar dan cerah, daun yang kuning berkurang, dan tanaman yang rontok daunnya mulai tumbuh daun-daun yang baru.

Pertumbuhan bibit anggrek $P$. amabilis pada perlakuan dengan pupuk Taichung + chitosan $10 \mathrm{ppm}$ dan perlakuan pupuk Taichung + chitosan $10 \mathrm{ppm}+$ pupuk guano $10 \mathrm{ml} \mathrm{L}^{-1}$ menunjukkan hasil yang tidak bagus karena saat bibit anggrek berumur 2 MSP akar mulai kering, daun mulai menguning dan ada sebagian daun yang menghitam. Pengendalian yang dilakukan yaitu dengan menghentikan aplikasi untuk semua perlakuan dan memberikan aplikasi vitamin B1 untuk memulihkan perakaran bibit anggrek yang kering, tetapi aplikasi vitamin B1 ini tidak berpengaruh terhadap bibit anggrek karena kondisi bibit anggrek dengan perlakuan P2 dan P4 semakin buruk bahkan hingga mati.

\section{Phalaenopsis bellina}

\section{Peubah Vegetatif}

Faktor tunggal pupuk organik guano dan chitosan tidak berpengaruh nyata terhadap panjang daun, lebar daun, jumlah daun dan tinggi tanaman. Tanaman yang diberikan perlakuan P1 yaitu pupuk Taichung $1 \mathrm{~g} \mathrm{~L}^{-1}$ pada kondisi panas dan kering untuk semua peubah vegetatif lebih baik bila dibandingkan dengan perlakuan lainnya. Tanaman yang diberi tambahan chitosan $10 \mathrm{ppm}$, guano $10 \mathrm{ml} \mathrm{L}^{-1}$, serta tambahan kombinasi chitosan $10 \mathrm{ppm}$ dan guano $10 \mathrm{ml} \mathrm{L}^{-1}$ menurun saat tanaman berumur 8-17 MSP (Tabel 1). Hal ini ini diduga tanaman yang diberi tambahan chitosan 10 ppm saat kondisi panas dan kering tidak dapat menyerap unsur hara karena tanaman tertutup oleh lapisan chitosan, sehingga daun menjadi keriput dan menguning, perakaran tanaman menjadi kering.

Suhu memiliki peranan penting dalam pertumbuhan dan pembungaan Phalaenopsis. Kebutuhan suhu sekitar $18-26{ }^{\circ} \mathrm{C}$. Anggrek Phalaenopsis epifit membutuhkan cahaya $1000-1$ $500 \mathrm{fc}$ atau penyinaran sinar matahari sekitar 10$30 \%$. Sementara kelembapan yang dibutuhkan 
cukup tinggi, sekitar 60-75\% (Dewi, 2006).

Tabel 1. Peubah vegetatif $P$. bellina

\begin{tabular}{|c|c|c|c|c|}
\hline \multirow{2}{*}{ Minggu ke- } & \multicolumn{4}{|c|}{ Perlakuan } \\
\hline & $\mathrm{P} 1$ & $\mathrm{P} 2$ & P3 & P4 \\
\hline & \multicolumn{4}{|c|}{ Panjang Daun $(\mathrm{cm})}$. \\
\hline 0 & 12.17 & 12.92 & 11.82 & 14.64 \\
\hline 4 & 12.22 & 13.01 & 11.94 & 14.78 \\
\hline 8 & 12.36 & 13.07 & 12.05 & 14.95 \\
\hline 12 & 12.46 & 12.74 & 11.06 & 13.90 \\
\hline 16 & 12.50 & 11.85 & 11.16 & 13.71 \\
\hline \multirow[t]{2}{*}{17} & 12.58 & 11.84 & 11.16 & 13.68 \\
\hline & \multicolumn{4}{|c|}{ Lebar Daun } \\
\hline 0 & 5.52 & 5.86 & 6.31 & 6.62 \\
\hline 4 & 5.68 & 5.95 & 6.41 & 6.74 \\
\hline 8 & 5.75 & 6.08 & 6.47 & 6.81 \\
\hline 12 & 5.77 & 6.15 & 6.06 & 6.12 \\
\hline 16 & 5.78 & 5.62 & 6.06 & 5.88 \\
\hline \multirow[t]{2}{*}{17} & 5.84 & 5.68 & 6.05 & 5.82 \\
\hline & \multicolumn{4}{|c|}{...Tinggi Tanaman $(\mathrm{cm})$. } \\
\hline 0 & 13.66 & 14.44 & 13.36 & 16.17 \\
\hline 4 & 13.75 & 14.62 & 13.50 & 16.36 \\
\hline 8 & 13.81 & 14.72 & 13.45 & 16.41 \\
\hline 12 & 13.85 & 14.20 & 12.36 & 15.10 \\
\hline 16 & 13.93 & 13.25 & 12.50 & 15.01 \\
\hline \multirow[t]{2}{*}{17} & 13.95 & 13.30 & 12.57 & 15.01 \\
\hline & \multicolumn{4}{|c|}{.Jumlah Daun... } \\
\hline 0 & 4.0 & 3.5 & 3.4 & 4.0 \\
\hline 4 & 4.4 & 3.6 & 3.4 & 4.0 \\
\hline 8 & 4.2 & 4.0 & 3.4 & 3.9 \\
\hline 12 & 4.4 & 3.5 & 3.5 & 3.6 \\
\hline 16 & 4.0 & 2.6 & 3.4 & 3.1 \\
\hline 17 & 4.0 & 2.6 & 3.4 & 3.0 \\
\hline
\end{tabular}

Keterangan: $\mathrm{P} 1=$ Pupuk Taichung $1 \mathrm{~g} \mathrm{~L}^{-1}, \mathrm{P} 2=$ Taichung + chitosan 10 ppm, $\mathrm{P} 3=$ Taichung + guano $10 \mathrm{ml}$ $\mathrm{L}^{-1} ; \mathrm{P} 4=$ Taichung + chitosan $10 \mathrm{ppm}+$ guano $10 \mathrm{ml} \mathrm{L}^{-1}$

\section{Peubah Generatif}

Berdasarkan uji $\mathrm{t}$ perlakuan pupuk Taichung $1 \mathrm{~g} \mathrm{~L}^{-1}+$ chitosan $10 \mathrm{ppm}$, pupuk Taichung $1 \mathrm{~g} \mathrm{~L}^{-1}+$ guano $10 \mathrm{ml} \mathrm{L}^{-1}$, pupuk Taichung $1 \mathrm{~g} \mathrm{~L}^{-1}+$ chitosan $10 \mathrm{ppm}+$ guano 10 $\mathrm{ml} \mathrm{L}{ }^{-1}$ tidak berbeda nyata terhadap perlakuan pupuk Taichung $1 \mathrm{~g} \mathrm{~L}^{-1}$ pada peubah panjang tangkai bunga, jumlah kuntum bunga, jumlah kuntum bunga per tangkai, dan ukuran bunga. Jarak dari ujung lips (bibir bunga) ke ujung sepal tertinggi lebih besar dibandingkan dengan jarak dari ujung petal ke ujung petal lainnya untuk semua perlakuan yaitu pupuk Taichung $1 \mathrm{~g} \mathrm{~L}^{-1}$, pupuk Taichung + chitosan 10 ppm, pupuk Taichung + guano $10 \mathrm{ml} \mathrm{L}^{-1}$, dan pupuk Taichung + chitosan $10 \mathrm{ppm}+$ guano $10 \mathrm{ml} \mathrm{L}^{-1}$. Kondisi anggrek yang diberi tambahan perlakuan chitosan $10 \mathrm{ppm}$ dan guano $10 \mathrm{ml} \mathrm{L}^{-1}$ baik, sebelum cuaca panas dan kering, sedangkan saat cuaca panas dan kering kondisi anggrek mulai tidak stabil, yaitu tangkai bunga menguning, kuntum bunga gugur, dan bunga tidak mekar sempurna (Tabel 2).

Tabel 2. Peubah generatif $P$. bellina

\begin{tabular}{|c|c|c|c|c|}
\hline \multirow{2}{*}{$\begin{array}{c}\text { Minggu } \\
\text { ke- }\end{array}$} & \multicolumn{4}{|c|}{ Perlakuan } \\
\hline & $\mathrm{P} 2$ & P3 & $\mathrm{P} 4$ & $\mathrm{P} 1$ \\
\hline & \multicolumn{4}{|c|}{....Panjang Tangkai Bunga $(\mathrm{cm}) \ldots .}$. \\
\hline 0 & 1.90 & 1.35 & 1.41 & 2.25 \\
\hline 4 & 2.81 & 1.68 & 2.76 & 2.53 \\
\hline 8 & 2.71 & 0.56 & 2.49 & 1.22 \\
\hline 12 & 0.75 & 0.67 & 2.51 & 1.43 \\
\hline 16 & 1.71 & 0.86 & 2.54 & 0.12 \\
\hline \multirow[t]{2}{*}{17} & 1.75 & 0.84 & 2.05 & 0.76 \\
\hline & \multicolumn{4}{|c|}{.Jumlah Kuntum Bunga... } \\
\hline 1 & 0.12 & - & 0.12 & 0.12 \\
\hline 9 & 0.25 & 0.37 & 0.25 & 0.12 \\
\hline 10 & 0.12 & 0.37 & 0.12 & 0.12 \\
\hline \multirow[t]{2}{*}{11} & 0.12 & 0.25 & 0.12 & 0.12 \\
\hline & \multicolumn{4}{|c|}{.Jumlah Kuntum Bunga per Tangkai.... } \\
\hline 2 & 0.25 & - & 0.12 & 0.25 \\
\hline 4 & 0.37 & - & 0.12 & 0.25 \\
\hline 9 & 0.5 & 0.25 & 0.5 & 0.12 \\
\hline 12 & 0.37 & 0.25 & 0.37 & 0.12 \\
\hline 14 & 0.25 & 0.25 & 0.25 & 0.12 \\
\hline \multicolumn{5}{|l|}{$\begin{array}{l}\text { Ukuran } \\
\text { bunga }\end{array}$} \\
\hline & \multicolumn{4}{|c|}{$\begin{array}{l}\text {....Jarak antara Ujung Petal ke Ujung Petal } \\
\qquad(\mathrm{cm}) \ldots . .\end{array}$} \\
\hline 3 & 0.5 & - & - & 0.47 \\
\hline 5 & 0.5 & - & - & 0.5 \\
\hline \multirow[t]{2}{*}{14} & - & 0.44 & 0.53 & 0.5 \\
\hline & \multicolumn{4}{|c|}{$\begin{array}{l}\text {.....Jarak antara Ujung Petal ke Ujung Petal } \\
\qquad(\mathrm{cm}) \ldots . .\end{array}$} \\
\hline 3 & 0.63 & - & - & 0.5 \\
\hline 5 & 0.75 & - & - & 0.5 \\
\hline 14 & - & 0.45 & 0.53 & 0.5 \\
\hline Keteranga & $\begin{array}{l}\mathrm{P} 1=\mathrm{Pu} \\
\text { chitosar } \\
\mathrm{L}^{-} 1, \mathrm{P} 4 \\
10 \mathrm{ml} \mathrm{L}\end{array}$ & $\begin{array}{l}\text { aichun, } \\
\text { m, P3 } \\
\text { hung + }\end{array}$ & $\begin{array}{l}-1, \mathrm{P} 2= \\
\text { hung }+ \\
\text { san } 10\end{array}$ & $\begin{array}{l}\text { chung + } \\
\text { no } 10 \mathrm{~m} \\
+ \text { guano }\end{array}$ \\
\hline
\end{tabular}

Perlakuan pupuk organik guano dan chitosan pada anggrek $P$. bellina belum dapat mempercepat pembungaan, hal ini dapat dilihat pada ulangan pertama persentase berbunga $0 \%$, tetapi pada ulangan kedua $100 \%$ untuk perlakuan $\mathrm{P} 1, \mathrm{P} 3, \mathrm{P} 4$, sedangkan $50 \%$ untuk perlakuan $\mathrm{P} 2$. Ulangan ketiga dengan perlakuan P4 memiliki persentase berbunga $100 \%$, sedangkan ulangan keempat dengan perlakuan pupuk P2 memiliki persentase berbunga sebesar 50\%. Masing-masing perlakuan tidak memberikan pengaruh yang nyata terhadap pembungaan, karena masing-masing perlakuan berbunga meskipun tidak dalam waktu yang sama. Perlakuan P2 dan P3 lebih lama atau lebih tahan dibandingkan dengan perlakuan P1 dan P4 dalam hal daya tahan bunga dan masa pembungaan. Hal lain yang menyebabkan daya tahan bunga tidak bertahan lama yaitu bunga terserang hama Sitophilus sp. sehingga bunga 
cepat layu.

\section{Waktu Keluar Bakal Bunga}

Waktu keluar bakal bunga adalah diamati saat tanaman sudah memperlihatkan tangkai bunga. Tidak semua tanaman anggrek $P$. bellina memiliki tangkai bunga, sehingga waktu keluar bakal bunga berbeda-beda. Waktu keluar bakal bunga pada anggrek $P$. bellina rata-rata setiap perlakuan berbeda, yaitu saat $0,1,3,5,8,9$, dan 17 MSP. Anggrek ini mulai tumbuh kuntum bunga dan berbunga sebelum kondisi iklim kering dan panas.

\section{Tingkat Kehijauan Daun}

Hasil uji t menunjukkan bahwa perlakuan pupuk organik dan chitosant idak berpengaruh nyata terhadap tingkat kehijauan daun anggrek $P$. bellina. Hal ini dapat terlihat dari hasil perbandingan $\mathrm{P} 1$ dengan $\mathrm{P} 2, \mathrm{P} 3$, dan $\mathrm{P} 4$ tidak terjadi perubahan yang signifikan. Pada P1, P3, dan P4 terjadi peningkatan tingkat kehijauan pada akhir pengamatan, sedangkan untuk P2 terjadi penurunan tingkat kehijauan daun (Tabel 3). Hal yang menyebabkan daun lebih hijau karena ukuran daun mengecil, sedangkan tingkat kehijauan daun menurun disebabkan kondisi cuaca yang kering dan panas, sehingga lamakelamaan warna daun memudar atau menjadi pucat.

Tabel 3. Perbandingan tingkat kehijauan daun $P$. bellina

\begin{tabular}{|c|c|c|c|c|}
\hline \multirow[b]{2}{*}{ Minggu ke- } & \multicolumn{4}{|c|}{ Perlakuan } \\
\hline & $\mathrm{P} 2$ & $\mathrm{P} 3$ & $\mathrm{P} 4$ & P1 \\
\hline & \multicolumn{4}{|c|}{.Tingkat Kehijauan Daun. } \\
\hline & 29.75 & 26.5 & 28.28 & 27.3 \\
\hline Akhir & 25.93 & 35.7 & 29.3 & 34.06 \\
\hline \multicolumn{5}{|c|}{$\begin{aligned} \text { Keterangan : } & \mathrm{P} 1=\text { Pupuk Taichung } 1 \mathrm{~g} \mathrm{~L}^{-1}, \mathrm{P} 2=\text { Taichung }+ \\
& \text { chitosan } 10 \mathrm{ppm}, \mathrm{P} 3=\text { Taichung }+ \text { guano } 10 \mathrm{~m} \\
& \mathrm{~L}^{-1}, \mathrm{P} 4=\text { Taichung }+ \text { chitosan } 10 \mathrm{ppm}+\text { guanc } \\
& 10 \mathrm{ml} \mathrm{L}^{-1}\end{aligned}$} \\
\hline
\end{tabular}

\section{Phalaenopsis modesta}

\section{Peubah Vegetatif}

Faktor tunggal pupuk organik guano dan chitosan tidak berpengaruh nyata terhadap panjang, lebar daun, tinggi tanaman, dan berbeda nyata terhadap jumlah daun pada 14-16 MSP. Pertumbuhan anggrek $P$. modesta pada kondisi kering dan panas lebih rentan dibandingkan dengan $P$. bellina, karena daun lebih mudah kuning dan gugur. Anggrek yang diberi perlakuan pupuk Taichung $1 \mathrm{~g} \mathrm{~L}^{-1}$ lebih tahan saat kondisi panas dan kering bila dibandingkan dengan anggrek yang diberi perlakuan tambahan chitosan $10 \mathrm{ppm}$ dan guano $10 \mathrm{ml} \mathrm{L}^{-1}$ (Tabel 4).

Gunawan (2006) menyatakan bahwa faktor cahaya yang berpengaruh terhadap pertumbuhan tanaman dibagi menjadi intensitas, lama penyinaran, serta kualitas sinarnya. Cahaya penuh akan menghanguskan daun, dan apabila dibiarkan terus-menerus akan menyebabkan kematian tanama

Virnanto (2010) menyatakan bahwa tanaman anggrek merupakan tipe tanaman yang memiliki kecepatan tumbuh yang relatif lambat. Cepat lambatnya pertumbuhan setiap jenis anngrek adalah berbeda-beda karena sangat tergantung dari segi pemeliharaan anggrek itu sendiri.

Tabel 4. Peubah vegetatif $P$. modesta

\begin{tabular}{|c|c|c|c|c|}
\hline \multirow{2}{*}{ Minggu ke } & \multicolumn{4}{|c|}{ Perlakuan } \\
\hline & $\mathrm{P} 1$ & $\mathrm{P} 2$ & P3 & $\mathrm{P} 4$ \\
\hline & \multicolumn{4}{|c|}{.Panjang Daun $(\mathrm{cm}) .}$. \\
\hline 0 & 9.51 & 10.19 & 9.50 & 9.50 \\
\hline 4 & 8.67 & 10.24 & 9.60 & 8.26 \\
\hline 8 & 8.80 & 10.37 & 8.92 & 8.38 \\
\hline 12 & 8.88 & 10.41 & 9.25 & 8.66 \\
\hline 16 & 8.35 & 7.57 & 8.60 & 5.85 \\
\hline \multirow[t]{2}{*}{17} & 8.36 & 7.58 & 8.67 & 5.85 \\
\hline & \multicolumn{4}{|c|}{ Lebar Daun $(\mathrm{cm})$. } \\
\hline 0 & 4.28 & 4.35 & 4.64 & 4.05 \\
\hline 4 & 4.00 & 4.48 & 4.47 & 3.55 \\
\hline 8 & 4.07 & 4.51 & 3.95 & 3.60 \\
\hline 12 & 4.10 & 4.47 & 4.18 & 3.65 \\
\hline 16 & 3.86 & 3.38 & 3.76 & 2.65 \\
\hline \multirow[t]{2}{*}{17} & 3.87 & 3.40 & 3.82 & 2.66 \\
\hline & \multicolumn{4}{|c|}{..Tinggi Tanaman $(\mathrm{cm})$. } \\
\hline 0 & 10.38 & 11.07 & 10.41 & 10.51 \\
\hline 4 & 9.56 & 11.51 & 10.67 & 9.11 \\
\hline 8 & 9.62 & 11.63 & 9.83 & 9.27 \\
\hline 12 & 9.71 & 11.60 & 10.33 & 9.41 \\
\hline 16 & 9.25 & 8.51 & 9.68 & 6.43 \\
\hline \multirow[t]{2}{*}{17} & 9.22 & 8.63 & 9.77 & 6.53 \\
\hline & \multicolumn{4}{|c|}{ Jumlah Daun.... } \\
\hline 0 & 4.0 & 3.1 & 3.0 & 3.6 \\
\hline 4 & 3.5 & 2.9 & 2.2 & 3.0 \\
\hline 8 & 3.6 & 3.0 & 2.5 & 2.9 \\
\hline 12 & 3.5 & 2.7 & 2.2 & 3.2 \\
\hline 14 & $3.5 \mathrm{a}$ & $2.1 \mathrm{ab}$ & $1.6 \mathrm{~b}$ & $2.1 \mathrm{ab}$ \\
\hline 15 & $3.5 \mathrm{a}$ & $1.7 \mathrm{~b}$ & $1.6 \mathrm{~b}$ & $1.7 \mathrm{~b}$ \\
\hline 16 & $3.4 \mathrm{a}$ & $1.4 \mathrm{~b}$ & $1.7 \mathrm{ab}$ & $1.7 \mathrm{ab}$ \\
\hline 17 & 3.4 & 1.5 & 1.7 & 1.9 \\
\hline $\begin{array}{r}\text { Keterangan: } \\
\mathrm{p} \\
\mathrm{y} \\
= \\
\mathrm{c} \\
\mathrm{I} \\
1\end{array}$ & \multicolumn{4}{|c|}{$\begin{array}{l}\text { Angka yang diikuti oleh huruf yang berbeda } \\
\text { pada baris yang sama menunjukkan perbedaan } \\
\text { yang nyata menurut uji BNJ pada taraf } 5 \% . \mathrm{P} 1 \\
=\text { Pupuk Taichung } 1 \mathrm{~g} \mathrm{~L} \mathrm{~L}^{-1}, \mathrm{P} 2=\text { Taichung }+ \\
\text { chitosan } 10 \mathrm{ppm}, \mathrm{P} 3=\text { Taichung }+ \text { guano } 10 \mathrm{ml} \\
\mathrm{L}^{-1}, \mathrm{P} 4=\text { Taichung }+ \text { chitosan } 10 \mathrm{ppm}+\text { guano } \\
10 \mathrm{ml} \mathrm{L}^{-1}\end{array}$} \\
\hline
\end{tabular}




\section{Peubah Generatif}

Berdasarkan uji $\mathrm{t}$ perlakuan pupuk Taichung $1 \mathrm{~g} \mathrm{~L}^{-1}+$ chitosan $10 \mathrm{ppm}$, pupuk Taichung $1 \mathrm{~g} \mathrm{~L}^{-1}+$ guano $10 \mathrm{ml} \mathrm{L}^{-1}$, pupuk Taichung $1 \mathrm{~g} \mathrm{~L}^{-1}+$ chitosan $10 \mathrm{ppm}+$ guano 10 $\mathrm{ml} \mathrm{L}^{-1}$ tidak berbeda nyata terhadap perlakuan pupuk Taichung $1 \mathrm{~g} \mathrm{~L}^{-1}$ pada peubah panjang tangkai bunga, jumlah kuntum bunga, jumlah kuntum bunga per tangkai, dan ukuran bunga. Jarak dari ujung petal ke ujung petal lainnya lebih besar dibandingkan dengan jarak ujung lips ke ujung sepal tertinggi untuk semua perlakuan (Tabel 5).

Tabel 5. Peubah generatif $P$. modesta

\begin{tabular}{|c|c|c|c|c|c|}
\hline \multirow{2}{*}{$\begin{array}{c}\text { Minggu } \\
\text { ke- }\end{array}$} & \multicolumn{5}{|c|}{ Perlakuan } \\
\hline & $\mathrm{P} 2$ & P3 & $\mathrm{P} 4$ & P1 & \\
\hline \multicolumn{6}{|c|}{..Panjang Tangkai Bunga $(\mathrm{cm}) . . . .}$. \\
\hline 0 & 1.81 & - & 1.18 & 0.91 & \\
\hline 1 & - & 0.48 & - & 1.56 & \\
\hline 4 & 2.14 & 0.93 & 1.78 & 1.43 & \\
\hline 8 & 2.39 & 0.7 & 1.83 & 1.59 & \\
\hline 12 & 2.01 & - & 1.71 & 1.46 & \\
\hline 14 & - & 1 & - & 1.53 & \\
\hline 16 & 1.35 & 0.69 & 1.79 & 1.56 & \\
\hline 17 & 1.44 & 0.69 & 1.82 & 1.61 & \\
\hline \multicolumn{6}{|c|}{.......Jumlah Kuntum Bunga.. } \\
\hline 0 & 0.37 & - & 0.12 & 0.25 & \\
\hline 4 & 0.25 & - & - & 0.25 & \\
\hline 6 & 0.37 & 0.12 & 0.37 & 0.25 & \\
\hline 8 & 0.12 & - & - & 0.12 & \\
\hline 12 & 0.25 & - & - & 0.12 & \\
\hline 14 & & 0.25 & 0.25 & 0.37 & \\
\hline \multirow[t]{2}{*}{17} & 0.12 & - & - & 0.25 & \\
\hline & \multicolumn{5}{|c|}{..Jumlah Kuntum Bunga per Tangkai..... } \\
\hline 0 & 0.25 & - & 0.12 & 0.12 & \\
\hline 4 & 0.37 & 0.12 & - & 0.37 & \\
\hline 8 & 0.12 & 0.25 & - & 0.25 & \\
\hline 12 & 0.25 & - & 0.25 & 0.25 & \\
\hline 17 & 0.25 & 0.25 & 0.12 & 0.25 & \\
\hline \multirow{2}{*}{\multicolumn{6}{|c|}{$\begin{array}{l}\text { Ukuran } \\
\text { Bunga }\end{array}$}} \\
\hline & & & & & \\
\hline \multicolumn{6}{|c|}{......Jarak antara Ujung Petal ke Ujung } \\
\hline & \multicolumn{5}{|c|}{ Petal $(\mathrm{cm}) \ldots \ldots$} \\
\hline 3 & 0.32 & 0.3 & 0.31 & 0.18 & \\
\hline 4 & 0.32 & 0.3 & 0.31 & 0.18 & \\
\hline 5 & - & - & 0.31 & 0.18 & \\
\hline 8 & 0.38 & 0.21 & - & 0.31 & \\
\hline \multirow[t]{2}{*}{10} & 0.31 & 0.46 & - & 0.63 & \\
\hline & \multicolumn{5}{|c|}{$\begin{array}{c}\text {..Jarak antara Ujung Lips dengan Ujung } \\
\text { Sepal Tertinggi }(\mathrm{cm}) \ldots . .\end{array}$} \\
\hline 3 & 0.25 & 0.27 & 0.1 & & 0.17 \\
\hline 4 & 0.25 & 0.27 & 0.1 & & 0.17 \\
\hline 5 & - & - & 0.1 & & 0.17 \\
\hline 8 & 0.26 & 0.15 & - & & 0.25 \\
\hline 10 & 0.16 & 0.27 & - & & 0.56 \\
\hline
\end{tabular}

Anggrek P. modesta perlakuan P1, P2, $\mathrm{P} 3$, dan $\mathrm{P} 4$ belum dapat mempercepat proses pembungaan. Pembungaan hanya terjadi pada ulangan pertama, karena pada ulangan pertama yang tumbuh tangkai bunga. Persentase berbunga pada ulangan pertama yaitu $100 \%$ untuk perlakuan $\mathrm{P} 1,100 \%$ untuk perlakuan $\mathrm{P} 2,50 \%$ untuk P3, dan $100 \%$ untuk P4 sedangkan untuk ulangan 2,3 , dan 4 yaitu $0 \%$. Daya tahan bunga dan masa pembungaan pada P1 dan P2 dari awal hingga akhir perlakuan semakin menurun, hal ini disebabkan karena kondisi iklim yang sangat panas sehingga bunga mudah layu dan gugur. Sedangkan pada P3 dan P4 daya tahan bunga dan masa pembungaan cenderung stabil.

Utami (2007) menyatakan bahwa kecepatan pertumbuhan anggrek berbeda-beda untuk setiap jenisnya, termasuk pembentukan primodial bunga. Anggrek agar cepat berbunga diperlukan perawatan, antara lain penyiraman sesuai kebutuhan, pemupukan diberikan sesuai fase pertumbuhan, pencegahan hama dan penyakit, suhu lingkungan, fotoperiodisitas (lama penyinaran terhadap rangsangan pembungaan) harus dilakukan. Anggrek Phalaenopsis akan berbunga setelah 8-10 bulan dalam pot tunggal.

\section{Waktu Keluar Bakal Bunga}

Waktu keluar bakal bunga diamati saat tanaman sudah memoerlihatkan tangkai bunga. Waktu keluar bakal bunga untuk tanaman anggrek $P$. modesta hanya pada ulangan 1 , sedangkan untuk ulangan 3 dan 4 hanya bertahan 1-2 minggu. Rata-rata waktu keluar bakal bunga saat tanaman berumur $0,1,2$, dan 3 MSP.

\section{Tingkat Kehijauan Daun}

Hasil uji t menunjukkan perlakuan pupuk organik guano dan chitosan tidak berpengaruh nyata terhadap tingkat kehijauan daun anggrek $P$. modesta. Hal ini disebabkan karena daun lama kelamaan menjadi pucat. Faktor yang menyebabkan daun menjadi pucat yaitu kondisi iklim yang tidak sesuai dengan syarat pertumbuhan anggrek, sehingga tingkat kehijauan anggrek menurun pada pengamatan akhir (Tabel $6)$.

Gunawan (2006) menyatakan bahwa nitrogen dibutuhkan untuk sintesis asam-asam amino, protein, asam nukleat, berbagai koenzim, dan sebagai konstituen molekul klorofil (zat hijau daun). Tanaman yang kekurangan nitrogen menunjukkan gejala daun yang berwarna hijau muda hingga hijau kekuningan. 
Tabel 6. Tingkat kehijauan daun P. modesta

\begin{tabular}{ccccc}
\hline Minggu & \multicolumn{4}{c}{ Perlakuan } \\
\cline { 2 - 5 } ke- & P2 & P3 & P4 & P1 \\
\hline & $\ldots \ldots \ldots \ldots$ & Tingkat Kehijauan Daun........... \\
Awal & 29.04 & 28.05 & 32.34 & 26.73 \\
Akhir & 22.76 & 24.63 & 16.3 & 26.58 \\
\hline
\end{tabular}

Keterangan: P1 = Pupuk Taichung $1 \mathrm{~g} \mathrm{~L}^{-1}, \mathrm{P} 2=$ Taichung + chitosan $10 \mathrm{ppm}, \mathrm{P} 3=$ Taichung + guano $10 \mathrm{ml}$ $\mathrm{L}^{-1}, \mathrm{P} 4=$ Taichung + chitosan $10 \mathrm{ppm}+$ guano $10 \mathrm{ml} \mathrm{L}^{-1}$

\section{Bibit anggrek $P$. amabilis}

Faktor tunggal perlakuan pupuk guano dan chitosan berpengaruh nyata terhadap panjang, lebar, jumlah daun, dan tinggi tanaman. Perlakuan yang sama tidak berpengaruh nyata terhadap lebar dan jumlah daun saat sebelum aplikasi (0 MSP). Parameter pengamatan panjang, lebar, dan jumlah daun meningkat dari minggu sebelum pengamatan sampai 2 MSP untuk perlakuan pupuk Taichung 1 $\mathrm{g} \mathrm{L}^{-1}$ dan perlakuan pupuk Taichung + guano 10 $\mathrm{ml} \mathrm{L}^{-1}$, sedangkan untuk perlakuan pupuk Taichung + chitosan $10 \mathrm{ppm}$ dan perlakuan pupuk chitosan $10 \mathrm{ppm}+$ guano $10 \mathrm{ml} / \mathrm{l}$ menurun (Tabel 7). Tanaman aklimatisasi lebih rentan dibandingkan dengan tanaman dewasa pada fase pembibitan, sehingga ketika diberi chitosan proses pengambilan air dan hara oleh daun menurun.

Tabel 7. Pertumbuhan bibit anggrek $P$. amabilis

\begin{tabular}{lccccc}
\hline & & \multicolumn{4}{c}{ Perlakuan } \\
\cline { 2 - 5 } Peubah & MSP & P1 & P2 & P3 & P4 \\
\hline Panjang Daun & 0 & $6.07 \mathrm{~b}$ & $7.83 \mathrm{a}$ & $6.89 \mathrm{ab} 6.88 \mathrm{ab}$ \\
& 2 & $6.11 \mathrm{bc} 6.86 \mathrm{ab}$ & $7.57 \mathrm{a}$ & $5.43 \mathrm{c}$ \\
Lebar Daun & 0 & $1.22 \mathrm{a}$ & $1.49 \mathrm{a}$ & $1.55 \mathrm{a}$ & $1.41 \mathrm{a}$ \\
& 2 & $1.53 \mathrm{ab}$ & $1.32 \mathrm{~b}$ & $1.83 \mathrm{a}$ & $1.19 \mathrm{~b}$ \\
Tinggi Tanaman & 0 & $7.05 \mathrm{~b}$ & $8.95 \mathrm{a}$ & $8.03 \mathrm{ab} 8.21 \mathrm{ab}$ \\
& 2 & $6.93 \mathrm{~b}$ & $7.64 \mathrm{ab}$ & $8.47 \mathrm{a}$ & $6.49 \mathrm{~b}$ \\
Jumlah Daun & 0 & $4.87 \mathrm{a}$ & $4.53 \mathrm{a}$ & $4.27 \mathrm{a}$ & $5.13 \mathrm{a}$ \\
& 2 & $6.20 \mathrm{a}$ & $3.07 \mathrm{~b}$ & $6.07 \mathrm{a}$ & $3.80 \mathrm{~b}$ \\
\hline
\end{tabular}

Keterangan: Angka yang diikuti oleh huruf yang berbeda pada baris yang sama menunjukkan perbedaan yang nyata menurut uji DMRT pada taraf 5\%. P1 = Pupuk Taichung $1 \mathrm{~g}$ $\mathrm{L}^{-1}, \mathrm{P} 2=$ Taichung + chitosan $10 \mathrm{ppm}, \mathrm{P} 3=$ Taichung + guano $10 \mathrm{ml} \mathrm{L}^{-1}, \mathrm{P} 4=$ Taichung + chitosan $10 \mathrm{ppm}+$ guano $10 \mathrm{ml} \mathrm{L}^{-1}$

Berdasarkan hasil uji t, perlakuan pupuk Taichung + guano $10 \mathrm{ml} \mathrm{L}^{-1}$ tidak berbeda nyata terhadap pupuk Taichung $1 \mathrm{~g} \mathrm{~L}^{-1}$ pada peubah tinggi tanaman, panjang, lebar, dan jumlah daun. Perlakuan pupuk Taichung + guano $10 \mathrm{ml} \mathrm{L}^{-1}$ lebih baik dibandingkan dengan pupuk Taichung $1 \mathrm{~g} \mathrm{~L}^{-1}$ (Tabel 8).

Kondisi bibit anggrek pada awal aplikasi yaitu saat bibit berumur 1-2 MSP masih menunjukkan hasil yang baik untuk semua perlakuan (P1, P2, P3, P4), tetapi saat bibit berumur 3-4 MSP kondisi perakaran mulai kering dan daun mulai menguning sehingga bibit anggrek mati untuk perlakuan P2 dan P4. Hal ini diduga konsentrasi chitosan yang diberikan terlalu tinggi untuk ukuran bibit atau perlakuan chitosan tidak cocok untuk bibit anggrek.

Perlakuan yang baik secara visual pada percobaan ini adalah perlakuan Taichung + guano $10 \mathrm{ml} \mathrm{L}^{-1}$, hal ini ditandai dengan kondisi bibit anggrek dari awal sampai akhir aplikasi lebih cerah dan segar dibandingkan dengan perlakuan pupuk Taichung $1 \mathrm{~g} \mathrm{~L}^{-1}$.

Tabel 8. Perbandingan antara perlakuan pupuk Taichung + guano $10 \mathrm{ml} \mathrm{L}^{-1}$ dengan perlakuan pupuk Taichung $1 \mathrm{~g} \mathrm{~L}^{-1}$

\begin{tabular}{cccc}
\hline & \multicolumn{3}{c}{ Taichung +} \\
Peubah & MSP guano $10 \mathrm{ml} \mathrm{L}^{-1}$ & $\begin{array}{c}\text { Puk Taichung } \\
1 \mathrm{~g} \mathrm{~L}^{-1}\end{array}$ \\
\hline Panjang Daun & 4 & 7.69 & 6.11 \\
& 6 & 7.39 & 6.19 \\
Lebar Daun & 8 & 7.47 & 5.93 \\
& 4 & 1.75 & 1.38 \\
Tinggi Tanaman & 6 & 1.75 & 1.39 \\
& 8 & 1.77 & 1.28 \\
Jumlah Daun & 6 & 8.62 & 6.95 \\
& 8 & 8.32 & 6.83 \\
& 4 & 5.6 & 6.53 \\
& 6 & 5.6 & 6.93 \\
& 8 & 5.73 & 6.4 \\
\hline
\end{tabular}

Pupuk guano mengandung nitrogen, fosfor, dan potassium yang baik untuk mendukung pertumbuhan, merangsang akar, dan kekuatan batang tanaman. Kotoran kelelawar yang sudah mengendap lama di dalam dasar gua akan bercampur dengan tanah dan bakteri pengurai (Sugianto, 2010).

\section{KESIMPULAN}

Pemberian pupuk organik guano dan chitosan tidak memberikan pengaruh terhadap pertumbuhan dan perkembangan beberapa anggrek Phalaenopsis, yaitu $P$. bellina, $P$. modesta, dan bibit $P$. amabilis. Anggrek $P$. bellina dan $P$. modesta lebih tahan pada kondisi panas dan kering bila diberikan pupuk Taichung 1 $\mathrm{g} \mathrm{L}^{-1}$ daripada pupuk Taichung + chitosan 10 ppm, pupuk Taichung + guano $10 \mathrm{ml} \mathrm{L}^{-1}$, dan pupuk Taichung + chitosan $10 \mathrm{ppm}+$ guano 10 $\mathrm{ml} \mathrm{L}^{-1}$. Konsentrasi chitosan $10 \mathrm{ppm}$ terlalu tinggi untuk bibit anggrek $P$. amabilis, sehingga menyebabkan kematian bibit. Pemeliharaan bibit cukup dengan pemberian pupuk Taichung $1 \mathrm{~g} \mathrm{~L}^{-1}$ ditambah pupuk guano $10 \mathrm{ml} \mathrm{L}^{-1}$. 


\section{DAFTAR PUSTAKA}

Chandrkrachang, S. 2002. The application of chitin in agriculture in Thailand. Advances in Chittin Science 5:458-462.

Dewi, T. Q. 2006. Menanam Anggrek di Pohon. Jakarta (ID): Penebar Swadaya.

Gunawan, L. W. 2006. Budidaya Anggrek. Jakarta (ID): Penebar Swadaya.

Sandra, E. 2005. Membuat Anggrek Rajin Berbunga. Jakarta (ID): Agromedia Pustaka.
Seta, R. M. 2009. Guano, Kotoran Burung yang Menyuburkan [Internet]. [diunduh 2011 Jan 25]. Tersedia pada: http://www.ideaonline.co.id/iDEA/Blog/T aman/Guano-Kotoran-Burung yangMenyuburkan.

Sugianto, E. 2010. Pupuk Organik dari Guano [Internet]. [diunduh 2011 Feb 01]. Tersedia pada: http://guanophosphat. blogspot.com/2010/11/pupuk-organikdari-guano.

Virnanto. 2010. Prospek dan Manfaat Anggrek (Phalaenopsis amabilis) [Internet]. [diunduh 2011 Feb 02]. Tersedia pada: http://matematikacerdas.wordpress.com/2 010/01/10/budidaya-anggrek phalaenopsis-amabilis/. 